This item was submitted to Loughborough's Research Repository by the author.

Items in Figshare are protected by copyright, with all rights reserved, unless otherwise indicated.

\title{
An assessment of biogas as a domestic energy source in rural Kenya: Developing a sustainable business model
}

PLEASE CITE THE PUBLISHED VERSION

https://doi.org/10.1016/j.renene.2018.01.032

\section{PUBLISHER}

(C) Elsevier

\section{VERSION}

AM (Accepted Manuscript)

\section{PUBLISHER STATEMENT}

This work is made available according to the conditions of the Creative Commons Attribution-NonCommercialNoDerivatives 4.0 International (CC BY-NC-ND 4.0) licence. Full details of this licence are available at: https://creativecommons.org/licenses/by-nc-nd/4.0/

\section{LICENCE}

CC BY-NC-ND 4.0

\section{REPOSITORY RECORD}

Hamid, R.G., and Richard Blanchard. 2019. "An Assessment of Biogas as a Domestic Energy Source in Rural Kenya: Developing a Sustainable Business Model”. figshare. https://hdl.handle.net/2134/28136. 


\title{
An Assessment of Biogas as a Domestic Energy Source in Rural Kenya: Developing a Sustainable Business Model
}

\author{
R.G.Hamid, R.E. Blanchard \\ r.e.blanchard@lboro.ac.uk
}

Centre for Renewable Energy Systems Technology, Loughborough University, LE11 3TU, UK.

\begin{abstract}
Energy poverty in the majority of the rural households in Kenya is a threat to economic and social development; hence the availability of an affordable and reliable domestic energy source is important. This study investigated: the potential resources for biogas for cooking, suitable anaerobic digesters that could be deployed in rural households, and also the viability of a small community biogas business model. Conservative estimates of the business model parameters and sensitivity analysis revealed that there was adequate biogas potential in central and western Kenya while water scarcity affected other regions' opportunities. Cattle manure was the predominant feedstock, although crop waste has possibilities to contribute to biogas production. Economically and technically, the inflatable tubular digester was found to be the most suitable type for biogas production in rural Kenya. Discounted cash flow analysis of the business model proved a profitable business to supply an affordable household energy at $0.55 € / \mathrm{Kg}$ of biogas, with projected household savings of $249 €$ annually. Labor cost was found to have high significance on the feasibility of the business model which was also sensitive to changes in biogas revenues. Kenya's rural areas have significant biogas potential to reduce energy poverty, generate income and aid social development.
\end{abstract}

\section{Keywords: Domestic energy, biogas resources, tubular digester, economic viability, biogas price, rural Kenya}

\section{INTRODUCTION}

Access to clean and affordable energy is essential for social and economic development, energy poverty is affecting the wellbeing and development of Kenyans in rural areas. The majority of rural households rely on biomass to meet their energy needs. There is a high dependence on wood biomass energy, leading to unbalanced supply and demand. The over reliance on unsustainable wood fuel leads to uncontrolled cutting of trees and shrubs in rural areas, with the situation worsened by climate and rainfall variability. Poor health conditions due to excessive exposure to indoors smoke emissions in the poorly ventilated houses in rural areas are prevalent. Less than 5\% of Kenyans use LPG as their primary cooking fuel, 5\% use kerosene, less than $1 \%$ use improved biomass cook stoves [1] and 90\% of rural households use firewood for cooking [2] [3]. A study by KIPPRA [4] stated that wood fuel, on average accounts, for $11.6 \%$ of for rural households' budgets. Electricity which is considered the perfect alternative to wood fuel and biomass energy remains out of reach for the majority. Only $4 \%$ of the population in rural areas are connected to the electricity grid due to the relatively high connection cost. In rural areas traditional biomass as fire [1]accounts for $97 \%$ of Kenya's domestic energy requirement and is mainly used for cooking. The deficit in firewood supplies has led to high rates of deforestation resulting in desertification, land degradation, droughts and famine.

\subsection{Biogas Penetration in Kenya}

Biogas was introduced in Kenya in 1950's, supposedly free of cost to the end user, as a pilot or demonstration project. Two types of biogas systems were introduced, the Chinese fixed dome digester, and the Indian floating drum digester. Through donation bodies and NGO's initiatives the technology was introduced in different rural areas in Kenya mostly utilizing cattle manure as the main biogas substrate. However, the installed biogas units didn’t succeed to disseminate biogas technology as desired. The barriers identified to market penetrations were found to be high construction and maintenance costs, lack of experience in constructing the units and maintaining the digesters in operating conditions. 
The aim of this study is to investigate the potential and the viability of biogas to provide clean and affordable domestic energy in rural Kenya. The objectives of this study are to review the potential resources to produce biogas in rural areas of Kenya, to investigate the types of anaerobic digesters currently in use, and to assess suitability of the available types of digesters to be deployed in rural Kenya, the last objective of this study is to assess the economic viability of a small community based biogas model.

\section{METHODOLOGY}

\subsection{Literature Review}

An initial literature review examined the conditions in Kenya that are required for biogas production. This examined feedstocks (cattle manure and crop wastes), water availability, land availability and farming practices. The review also covered the models of anaerobic digesters currently in use in Kenya, identifying the relative advantages and disadvantages of each type with special consideration to the economic situation in rural areas and the barriers to biogas adoption.

\subsection{Analysis of the Economic Viability of Biogas Energy from a Community Based Biogas Plant}

A small community based anaerobic digester was used to develop a biogas business model, with the suggested operation mode being designed to assess the feasibility and sensitivity of the biogas business model. The model assumed that five households get their daily cooking energy needs from the biogas produced. One of the farmers with an access to loan or personal funds will be the owner/entrepreneur who will install the plant in a proximity to the five households and manage all the plant's operations. The main objective of the business model was to provide continued, clean and affordable household energy at a cost less than the cost spent to acquire their energy needs from other sources.

Conservative estimation of the design and sizing parameters of the biogas anaerobic digester is crucial to avoid over sizing the biogas digester. Using the optimum biogas digester size enables farmers to acquire the technology since it is determined on the exact investment cost required. The methodology considered a range of techno-socio-economic parameters that are described in the following sections.

\subsubsection{Biogas Technical Parameters}

\subsubsection{Hydraulic Retention Time}

The hydraulic retention time (HRT) is the average time the substrate remains in a reactor vessel. A study by Sovacool et al. [5] indicated that one of the advantages of the tubular flexi biogas systems is its shorter retention days compared to other types of anaerobic digestion systems, the retention time according to the study was 15 days. A study by Preston et al,[6] mentioned that the retention time for pig manure in flexi biogas digester was 10-20 days, Biogas International Ltd. brochures indicate that the retention time in their flexi biogas systems in Kenya is 20-30 days. Through personal communication Biogas International Ltd, it was confirmed that the retention days can be as short as 10 retention days especially with the effect of the insulation provided by the greenhouse tent. Ileleji et al [7] state that plug flow digesters designs are suitable for cattle manure and operate semicontinuously with a retention time of 20-30 days. By considering the effect of the greenhouse tent the best estimate found to be 20 days as the biogas model hydraulic retention time.

\subsubsection{Substrate}

The assumption here was the five houses are keeping stall fed cattle (3-5 cows), a conservative estimate was based on the daily cattle manure production as per the data available from [8], [9], [10], and on the basis of the least cow weight (220kg), the average daily available substrate was estimated as $13.5 \mathrm{~kg}$ manure/cow/day, the maximum available cattle manure would be $337.5 \mathrm{~kg} /$ day (5 houses x 5 cattle), and the minimum $202.5 \mathrm{~kg} /$ day (5 houses x 3 cattle).

\subsubsection{Sizing of the biogas digester}

The size of the anaerobic digester was based on the amount of the biogas substrate and the retention time required to convert it to gas. According to the maximum quantity of $337.5 \mathrm{~kg}$ of cattle manure mixed with water at $1: 1$ the flow rate of $0.675 \mathrm{~m}^{3} / \mathrm{day}$ was expected, and by assigning $20 \%$ of the digester volume for gas, the daily digester volume needed is $0.843 \mathrm{~m}^{3}$. According to the estimated hydraulic retention days of 20 days, Equation 1, the optimum biogas digesters size is $16.875 \mathrm{~m}^{3}$, to be provided as two flexible biogas systems (FBS) each of $9 \mathrm{~m}^{3}$ capacity, giving around $1.2 \mathrm{~m}^{3}$ additional room for gas storage.

$\mathrm{V}_{\text {digester }}=\mathrm{HRT} * \mathrm{Q}_{\text {daily flow rate }}$ 


\subsubsection{Biogas production}

A study by Bhattacharya, et al [11], indicated that cattle manure dry matter as $2.86 \mathrm{~kg} / \mathrm{h} / \mathrm{d}$, volatile solids (VS). VS/DM (drymatter) as 0.934 give an equivalent VS of $2.67 \mathrm{~kg} / \mathrm{h} / \mathrm{d}$. The biogas specific yield as indicated by the study was given as $0.2 \mathrm{~m}^{3} / \mathrm{kg}$ VS, so the estimated daily biogas production amount equated to $13.35 \mathrm{~m}^{3}$ of gas per day.

An estimate of gas production was made in this research using equation 2. Daily cattle manure collection will be 337.5kg, dry matter (DM) $18 \%$ and the organic dry matter (ODM) $90 \%$ DM which yield daily ODM of $54.67 \mathrm{~kg}$. The estimated gas production based on (0.2-0.3) $\mathrm{m}^{3}$ biogas for each $\mathrm{kg}$ ODM is expected to be $13.67 \mathrm{~m}^{3} / \mathrm{d}$

Available substrate $* \mathrm{DM} \% * \mathrm{ODM}_{\mathrm{DM}} * 0.25 \mathrm{~m}^{3} / \mathrm{kg}$ ODM $=$ gas yield per day

Considering these findings and that of [11] the business model will be conservatively based on the referenced resource [11] at $13.35 \mathrm{~m}^{3} / \mathrm{d}$.

\subsubsection{Deliverable energy from fuels portfolio available}

The term deliverable energy was used to define the energy as the heat which can be utilized from each of the fuels according to the net calorific value and the efficiency of the stove in use (based on a normalized set of data), the data used to process this analysis was as follows:

- Cost data: The price of LPG, kerosene, charcoal were derived from the Kenya National Bureau of Statistics 2015 [12], fuel wood price [13] and personal communication.

- Net calorific values: wood fuel (MC 20\%) [14] charcoal and LPG [36], biogas calorific value [15], [16] estimated at methane upper calorific value of $11.06 \mathrm{kWh} / \mathrm{m}^{3}$ and $65 \%$ methane content.

- Fuel density data: since all fuels are considered by weight in kg, LPG density [17] biogas density [16] kerosene density [18] fuel wood and charcoal density[14].

- Stove efficiency data: Biogas and kerosene stove efficiency 55\% \& 50\% respectively [19].

This analysis was used to determine a reasonable and competitive biogas price to be supplied from the community based biogas plant. See Table 1.

\subsubsection{Estimation of capital and operational cost}

The exchange rate used in the study was: $1 €=113.307 \mathrm{KSh}, 1 \$=103.1 \mathrm{KSh}[20]$.

\subsubsection{Capital cost (Capex)}

As affirmed by the suitability analysis the tubular biogas digester was the favorable digester type. The flexi biogas system distributed in Kenya by Biogas International Ltd was used to set the biogas business model. According to the size of operation and the estimated technical parameters two units of Model BG6 were considered as appropriate. The cost of one unit was 76,000KSh [21], this cost include the flexi digester, all gas-lines, micro greenhouse tunnel, double burner stove, piping and fittings, and training on operation and maintenance [22]. These units are surface or ground mounted.

e.g. Two units of BG6 model (capacity of $9 \mathrm{~m}^{3}$ ) cost: 670.7 X $2=1,341 €$.

Contingency @ 10\%=134€ Total capital cost $=\underline{\mathbf{1 , 4 7 5 €}}$

Interest rate/ discount rate is considered as the cost of finance if credit facility is available and was assumed to be $3 \%$ based on the assumption of support or subsidy available for renewable energy projects.

\subsubsection{Operations and maintenance cost (Opex)}

The substrate, cattle manure, would be mixed with water in ratio of 1:1 (Cattle manure weight in kg: water volume in litres) [23], Utility water in Nairobi cost $0.41 € / \mathrm{m}^{3}=0.000414 € /$ Litre [24], [25]. Cattle manure was to be provided at zero cost and then to be offset by the digester effluent as an organic fertilizer. Labor cost used was the minimum workers wage in rural areas per day 296 $\mathrm{KSh}=2.6 €$ [26]. The model assumes one worker to run the daily operation, the business model assumed $5 \%$ of capital cost will suffice the annual maintenance costs, allocated to daily operational cost as $0.0137 \%$ capital cost/day.

\subsubsection{Socio economic parameters}

The Business model assumes an average house hold size of 5-6 persons. Cattle kept per household assumed as 3-5 cows. Firewood is the predominant fuel used for domestic energy in rural Kenya[27], [28] see Figure 1, with the annual consumption per capita of firewood at $714 \mathrm{~kg}$ corresponding to $10-12 \mathrm{~kg}$ for a 5-6 person household size, Dohoo et al. [13] stated that household wood fuel consumption in rural Kenya is $11.4 \mathrm{~kg} / \mathrm{day}$, while a stakeholder personal communication estimated daily average consumption of fuel wood around $10 \mathrm{~kg} / \mathrm{day}$. Considering the deliverable energy of $11.4 \mathrm{~kg}$ of wood fuel, the equivalent 
amount of daily kerosene and biogas consumption was calculated as $0.79 \mathrm{~kg}$ and $1.2 \mathrm{~kg}$ respectively (based on net calorific values, kerosene and biogas stove efficiency of 50\% and 55\% respectively), see Table 1.

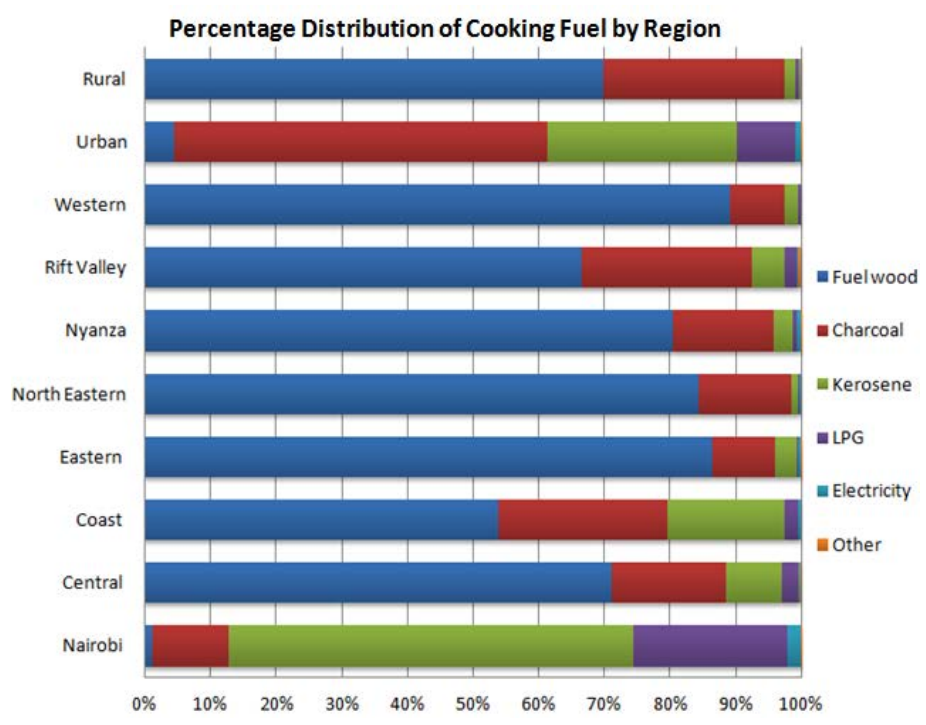

Figure 1: Distribution of cooking fuel by region

Table 1: Cost of delivered energy

\begin{tabular}{|l|ccccc|}
\hline & LPG & Kerosene & Charcoal & $\begin{array}{c}\text { Firewood } \\
20 \% M C\end{array}$ & Biogas \\
\hline & $€ / \mathrm{kg}$ & $€ / \mathrm{kg}$ & $€ / \mathrm{kg}$ & $€ / \mathrm{kg}$ & $€ / \mathrm{kg}$ \\
Price & 1.65 & 0.65 & 0.17 & 0.088 & 0.55 \\
CV kWh/kg & 12.90 & 11.80 & 8.05 & 4.10 & 7.00 \\
Stove efficiency & 0.49 & 0.50 & 0.28 & 0.10 & 0.55 \\
$\begin{array}{l}\text { Price } € / \text { kWh } \\
\begin{array}{l}\text { Price of delivered } \\
\text { energy } € / \text { kWh }\end{array}\end{array}$ & 0.13 & 0.06 & 0.02 & 0.022 & 0.08 \\
\hline
\end{tabular}

2.2.4 Valuation of the biogas from the community based biogas plant

According to the cost of delivered energy from each of the fuels in Table 1, the biogas price is estimated by reference to Kerosene's and to firewood's end user market price. Taking into account stove efficiencies $1 \mathrm{~kg}$ kerosene delivers $5.9 \mathrm{kWh}$ at the price of $0.654 € / \mathrm{kg}_{\mathrm{kerosene}}$ and $1 \mathrm{~kg}$ firewood delivers $0.4 \mathrm{kWh}$ at the price of $0.088 € / \mathrm{kg}$ firewood. In comparison, $1 \mathrm{~kg}$ biogas would deliver $3.85 \mathrm{kWh}$ at price of $0.55 € / \mathrm{kg}_{\text {biogas. }}$. It is important to note that despite kerosene being highly subsidized, firewood is the dominant form of fuel used for cooking (Figure 1) so its current price was used as benchmark for biogas pricing. The pricing objective aimed to make biogas more attractive to farmers through projected energy cost savings of around $30 \%$. It can be seen, from Table 1, the price for biogas is $0.14 € / \mathrm{kWh}$ or $65 \%$ of the price of firewood $(0.216 € / \mathrm{kWh})$.

\subsubsection{Valuation of slurry as fertilizer}

Smith [29] stated that bioslurry is an effective organic fertilizer. Emissions of the greenhouse gas, nitrous oxide, were significantly lower from crops treated with bioslurry than from those treated with urea. Furthermore, using bioslurry as a fertilizer can increase the crops yield by $25 \%$ and save the farmers more than 50 US\$ on the cost of chemical fertilizers which they usually find very expensive to obtain [30]. The digestate will be handled by the plant operator and distributed locally to the community avoiding the need for any transportation.

\subsubsection{Economic viability of community based biogas business model energy}

Using Microsoft Excel functions, discounted cash flow analysis for the biogas system during a life span period of 5 years was conducted using:

1- Net present value (NPV) at a marginal discount rate of 3\%, neither inflation rate nor depreciation are considered (small capex).

2- Discounted Payback period calculated based on the annual discounted cash flow.

3- Project internal rate of return (IRR) was calculated. 


\subsubsection{Current household energy costing}

Households in the rural areas of Kenya use a fuel mix portfolio to meet their domestic energy needs [27]. 86\% of the rural households use fire wood for cooking, 34\% use charcoal. In addition, 94\% use kerosene for lighting and also cooking, and only $1.8 \%$ of the rural households use LPG. The business model assumes that all the energy for cooking was paid for or provided at cost. The fuel price in $€ / \mathrm{kg}$ was used to determine the cost of energy delivered as shown in Table 1.

\subsubsection{Sensitivity analysis}

To determine the risks of significant impacts on the viability of the business model the implications of operating expenses, capital investment and biogas price on the NPV of the community based biogas plant was examined. The impact of the partial collection of daily produced manure was also considered by varying each of these parameters in steps of $10 \%$ within the range of $-50 \%$ to $+50 \%$. Moreover, the significance of each of the operating expenses parameters was also examined on the same basis.

\section{RESULTS AND DISCUSSION}

\subsection{Biogas Resources}

A study by Kiplagat et al. [31] identified the biogas technical potential as the numbers of households that have the essential requirements of sufficient dung and water. This was estimated to be 1.25 million households in Kenya. It was also claimed that if other types of bio-wastes rather than cattle manure were considered the estimated potential could be higher.

\subsubsection{Cattle manure}

A publication by the Kenya Smallholder Dairy Program SDP [32] asserted that the national cattle population is far more higher than the officially reported figures of 3 million cattle. Indeed, according to this ground truth survey results the Kenya cattle population was projected to be 6.7 million dairy cattle owned by 1.8 million rural farmers [32]. The availability of cattle manure in a confined area is important to fulfil the basic requirement of substrate availability. This is maintained through keeping cattle in zero grazing units. Different forms of cattle kept as free grazing will result in low substrate quantities or high operational costs.

The Kenya Biogas National Implementation Plan [33] identified the areas of households using zero grazing units and semi zero grazing units. This highlighted the western to central areas of Kenya, see Figure 2, as locations with high technical potential to adopt the household biogas technology. The SDP survey report stated that 74\% of the farmers owned agricultural lands and 73\% of these had dairy cattle [34]. This emphasizes the fact that dairy is a prevalent enterprise among rural households over a wide area of central Kenya. In addition, the farming system had significant statistical relationship with the adoption of the technology [19]. Zero grazing farming makes it easier and cheaper to operate the biogas plant in terms of cattle manure collection. The major competing usage of cattle manure as a biogas resource is selling it as an organic fertilizer. A study on cattle manure markets in central Kenya [35] revealed that the mean annual cattle manure sales were 5.7 million tonnes and a gross income per household of $1,350 \mathrm{KSh}(12 € /$ year $)$.

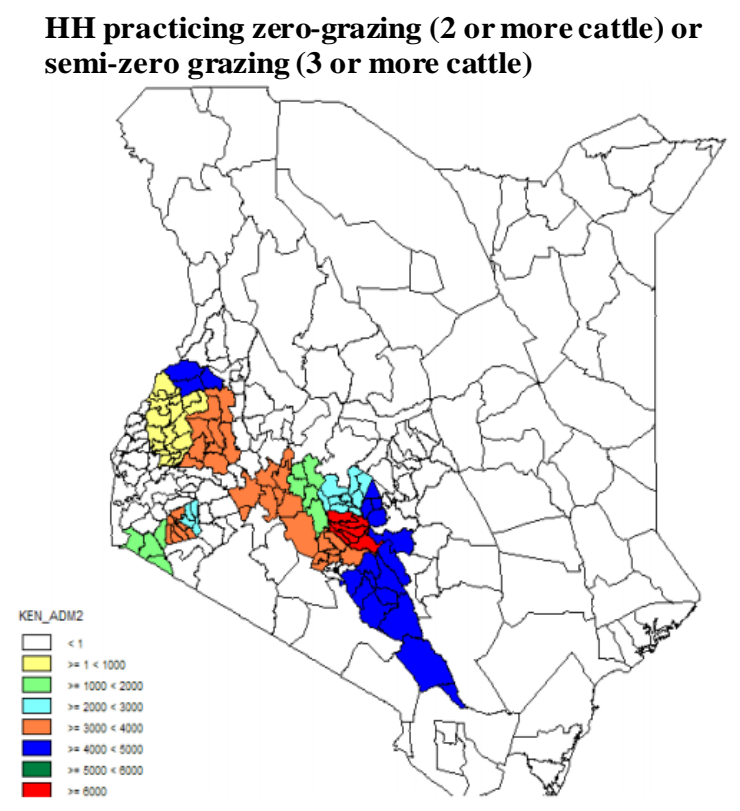

Figure 2: Households (HH) with zero or semi-zero grazing units [33] 


\subsubsection{Crops residues}

Nzila et al, [36] investigated Kenya's biogas potential as substrate available from crops residues. The study covered cotton, tea, maize, barley and sugarcane, and claimed that without compromising food security these crops residues provide abundant biogas substrate to produce 1,313 million cubic meters of methane annually, equivalent to 73\% of Kenya's annual energy demand. These residues could replace or supplement cattle manure in biogas digesters.

\subsubsection{Water}

Kenya is classified as a water scarce country. In general, access to safe water supplies throughout Kenya is 59\% [37] with the water needs for urban and most rural areas not met. In 2004 the government declared that the country was facing drought [38] and poor rainfall season was experienced up to January 2017 in the northern pastoral areas, southeastern and coastal marginal agricultural lowlands. In line with assessing biogas potential in rural areas; the research reports of the SDP provided specific data covering central Kenya's eight districts and highlighted inadequate water supply as a constraint to dairy farming development [34]. $90 \%$ and $30 \%$ of Nairobi and Nakuru farmers respectively used public piped water while the majority of the farmers (34\%), have on-farm shallow wells and $18 \%$ of the farmers buy water from private pumps at distance from the farm. In contrast, in 2002, the SDP research report in western Kenya [39] stated that only 5\% in Nakuru district have access to public piped water. Thus, presenting challenges on the data for public piped water; being neither available nor consistent. Water availability remains a critical challenge to the success, dissemination and viability of biogas technology.

\subsubsection{Land}

In terms of land productivity potential, ILRI [40] identified the area encompassing central Kenya through to the central Rift Valley to western Kenya and the coastal strip as areas of high agricultural potential with an annual rainfall of more than $750 \mathrm{~mm}$. The SDP survey report [34] covering central Kenyan provinces declared that about 74\% of all households owned agricultural land on a freehold land tenure. The mean land holding was estimated at 6.6 acres (2.7ha). Farmers in these regions were shifting to intensification with fodder planting and the use of stall-feeding cattle units. This intensification supports the technical biogas potential by shifting to zero grazing. However, land available for a biogas unit is not a default unless the opportunity costs for biogas (or the anticipated biogas benefits) outweigh other land usages. In the western provinces [39] the mean acreage for all households was smaller, on average 3.6 acres (1.45ha) with the largest proportion of land still as freehold (65\% of all households), Mwirigi et al. [19] stated in their study that, in Nakuru District, the size of the family land negatively affected the decision of adopting a biogas system, since here farmers had plots less than 2 acres (0.8ha). Land tenure affected technology adoption, as by using the title deed as security one can acquire credit, so possession of land on freehold as in these Kenyan regions could support the dissemination of biogas technology.

\subsection{Existing Types of Anaerobic Digestion in Rural Kenya}

\subsubsection{Fixed dome biogas digesters}

This type digester was first built in China as early as 1936. This digester consists of a closed dome-shaped masonry construction usually placed underground, built out of poured concrete, stones or bricks, the top and bottom are hemispherical and joined together by straight sides, the inner surface is sealed with several layers of plastering to make it gas tight, the inlet pipe is positioned straight at a side ending up at mid-level of the digester chamber. The effluent outlet also serves as a displacement pit or a compensation tank and the gas outlet pipe is placed at the top of the digester dome. The main chamber serves as digester and gas holder. As the gas produced builds up at the upper part of the dome; it displaces some of the slurry to the inlet pipe and the displacement tank and when gas is consumed the pressure drop back and the slurry sinks back. There is no mixing with the design and scum can accumulate on the top of the liquid substrate causing operational difficulties. The biogas digester is covered by earth up to the top of the dome for insulation and to counteract the internal pressure of the gas which is normally around (0.1-0.15 bar) [41], [42], [43]. Several modified designs are in use in Kenya, the Akut and CAMARTEC models are the most common type of fixed dome digesters. In 2009 a SNV feasibility survey results proposed a new modified fixed dome biogas digester, named Kenya Biogas model (KENBIM) its key features were the conical floor to withstand weak soil conditions, no manhole on top of the dome, a rectangular shape for the expansion chamber and a gas holder that stores $60 \%$ of the daily gas production [44], accordingly by 2011 the Kenya National Domestic Biogas Program implemented with 3239 plants [45]. 


\subsubsection{Floating drum biogas digesters}

This design was developed in India and is widely used in the developing world, The floating drum biogas [43] digester consists of a masonry cylindrical or dome-shaped digester with a cylindrical top and a movable floating gas-holder as a drum made of mild steel, which has been recently replaced by fiberglass re-enforced plastic to overcome the problem of corrosion. The digester chamber is built of brick, concrete or quarry-stone masonry with plaster. In some versions there are stirrer blades placed on the inside of the floating dome, so that the slurry can be stirred by turning the dome around. In case of the metal drum it is usually coated with an anti-corrosion material. The gasholder drum floats either directly on the fermenting slurry or in a separate water jacket. The drum has an internal and/or external guide frame that provides stability and keeps it upright [42]. As gas production proceeds, the drum is pushed up, indicating a rise in the amount of gas. When the gas is used up, the drum sinks back. The drum level thus provides a useful visual indicator of the quantity of gas available; the pressure of the gas available depends on the weight of the gas holder per unit area and usually varies between 4 and $8 \mathrm{~cm}$ of water column.

Sovacool et al., [5] stated that according to the 2009 partial biogas digester survey, there were over 284 floating drum biogas digesters in different parts of the Kenya with a cumulative installed capacity of over 4,424 $\mathrm{m}^{3}$. The Borda-sasse model is the most widely disseminated plant in Kenya, [46] It has performed very well under local conditions. The Hutchinson type, built and disseminated by a local company; Tunnel Technology Limited, is another model of the floating drum plant which has been available in Kenya since 1970.

Furthermore, on the floating drum principle, there are readymade domestic biogas plants available from Kentainers [47], these are compact biogas units basically formed of two linear low-density polyethylene tanks, the larger tank is referred to as the digester and the smaller is referred to as the dome and acts as the gas holder. The plant is simple to operate; it is sold as a kit and takes only two to three hours to install. The space needed is about $2 \mathrm{~m}$ square and $2.5 \mathrm{~m}$ high and the feedstock can be manure or food waste. Kentainers claims that if these units are properly managed it can produce sufficient gas for 3 hours of cooking daily.

\subsubsection{Inflatable tubular plug flow biogas digesters}

In general plug flow biogas digesters have a constant volume, but produce biogas at a variable pressure [48], while the requisite gas pressure can be obtained by placing weights on the bag. The inflatable tubular digesters [43] consist of a weather resistant, heat sealed and usually reinforced high density polyethylene (HDPE) plastic or rubber bag with an average length to width ratio of 5:1 equipped with inlet and outlet. The inlet and outlet of the digester are located at opposite ends and kept above ground, while the remaining parts of the digester is buried in the ground in an inclined position. As the fresh substrate is added from the inlet, the digestate flows towards the outlet at the other end of the tank. The inclined position makes it possible to separate acidogenesis and methanogenesis longitudinally, thus producing a two-phase system, see Figure 3. In order to avoid temperature fluctuations during the night and maintain the process temperature, a gable or shed roof is placed on top of the digester to cover it, which acts as an insulation both during day and night [43]. These systems are currently marketed in Kenya by Biogas International Ltd.

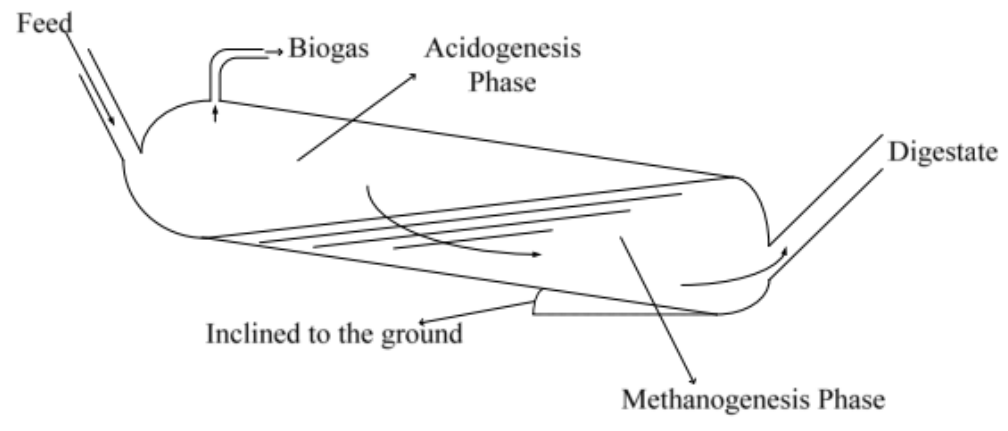

Figure 3: Schematic sketch of a plug flow digester [48]

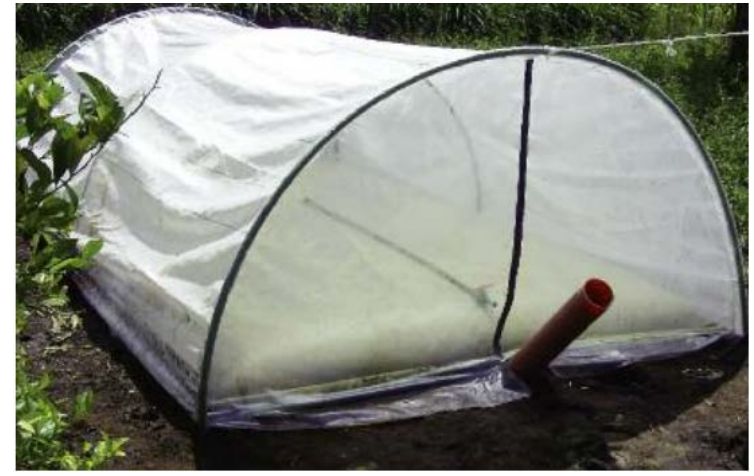

Figure 4: Flexi biogas system [49]

\subsubsection{Biogas International Flexi bag systems}

These systems are based on the plug flow inflatable tubular digesters. The main difference from the other tubular biogas systems is that it is insulated and placed above ground, so no civil work needed for a trench see Figure 4 (personal communication with Biogas International). This system consists of a PVC tarpaulin bag housed in a polyethylene greenhouse tunnel, the tunnel acts like an insulated jacket, trapping heat and keeping the temperature between 25 and $36^{\circ} \mathrm{C}$. The combination of the tunnel and the plastic bag increases the volume of gas production and reduces the retention time, ensuring a high rate of fermentation and gas 
production. Furthermore, the tunnel fabric serves as an ultraviolet shield, further extending the life of the digester. The systems now use a PVC tarpaulin bag that lasts at least 10 years, while the greenhouse tunnel would need to be replaced every 3-5 years. These systems have been installed in Kenya as part of a project titled Making Biogas Portable. It is an initiative funded through IFAD by the UK Department for International Development [49]. IFAD launched a pilot project in 2011 distributing 10 units in Kenya and based upon these pilot projects IFAD with Biogas International Ltd. worked on prototype development and market commercialization. They managed to distribute 500 units of these systems [30]. Nzila et al. [43] indicated that the installed biogas capacity in Kenya in 2009 was $8,733 \mathrm{~m}^{3}$, of which more than $4000 \mathrm{~m}^{3}$ was of the fixed dome and the floating drum type, while the tubular type was the least installed capacity at less than $1000 \mathrm{~m}^{3}$.

\subsection{The Suitability of Different Anaerobic Digesters to be Operated in Rural Kenya}

According to the literature review of the anaerobic digesters currently in use in Kenya the advantages and disadvantages of each type are summarized in Table 2.

Table 2: Advantages and disadvantages of three biogas digesters

\begin{tabular}{|c|c|c|}
\hline Digester Type & Advantages & Disadvantages \\
\hline Fixed dome digester & $\begin{array}{l}\text { Durable long lifetime } \\
\text { No moving or rusting parts included } \\
\text { Compact design, less land required } \\
\text { Easy operation } \\
\text { Long life span of } 15-20 \text { years } \\
\text { Compact and well-insulated design } \\
\text { Protected from temperature fluctuation }\end{array}$ & $\begin{array}{l}\text { Medium to high initial cost } \\
\text { Difficult to identify leaks } \\
\text { Irreparable/ difficult to maintain cracks } \\
\text { Fluctuating gas pressure } \\
\text { Skilled labor needed for construction } \\
\text { Masonry is prone to porosity and cracks[43] } \\
\text { Long retention days, } 45 \text { days for KENBIM[44] } \\
\text { No indication of gas volume } \\
\text { Heavy construction materials, and high transportation } \\
\text { cost }\end{array}$ \\
\hline $\begin{array}{l}\text { Floating drum } \\
\text { digester }\end{array}$ & $\begin{array}{l}\text { Stored gas volume is instantly recognizable } \\
\text { Steady gas pressure } \\
\text { Long lifetime of the digester (20 years) } \\
\text { Simple operation } \\
\text { Can be equipped with mixing devices } \\
\text { Compact design, less land }\end{array}$ & $\begin{array}{l}\text { High initial cost } \\
\text { Steel drum is expensive and maintenance intensive } \\
\text { Short lifetime of the steel drum (5years) } \\
\text { Construction is labor intensive } \\
\text { Heavy construction materials, and high transportation } \\
\text { cost }\end{array}$ \\
\hline Plug flow digester & $\begin{array}{l}\text { Low initial cost } \\
\text { Light weight easy to transport } \\
\text { No civil work needed } \\
\text { Easy low-cost maintenance } \\
\text { Less subject to temperature variation when } \\
\text { equipped with greenhouse tunnel } \\
\text { Efficient substrate fermentation } \\
\text { Portable and expandable systems } \\
\text { Easy to load, unblock and empty due to the open-ended } \\
\text { tube } \\
\text { Retention time } 15 \text { days }\end{array}$ & $\begin{array}{l}\text { Short life of greenhouse tunnel } \\
\text { High susceptible to damage } \\
\text { Low gas pressure needs regular control by adding } \\
\text { weights. } \\
\text { End of life disposal procedure unknown }\end{array}$ \\
\hline
\end{tabular}

The advantages of tubular biogas digesters enable farmers in rural Kenya to ovecome biogas dissemination barriers. In addition to the identified advantages, a study by Hagegård, [42] discussed the concept of a tank and a tube digester for anaerobic digesting. It claimed that the tube digester (plug flow type) is more efficient than the tank. In the tube digester the composition of the contents changes gradually all the way from the inlet to the outlet and there can be radial mixing of the contents, and the reactions go quicker at the beginning of the tube when the concentration is high. While in the tank digester, the contents immediately get diluted and a percentage of the fresh feed material is always flushed through the outlet without a sufficient retention time to ferment. In addition, there will be different bacteria active at different stages of fermentation in the tube digester, so that they can specialize in the conditions at that stage, however, in the tank there aren't different stages. Key benefits of the tube digester are it assures that no pathogens from the feed can go quickly through to the outlet, and thus the hygienization becomes more effective. Dohoo et al. [13] asserted that biogas digesters, analysed in a study, functioned equally well in summer and winter and were effective during the entire year.

A multi criteria sustainability assessment of biogas production in Kenya by Nzila et al [43] revealed that the tubular digester offered the highest energy autonomy per unit of investment and had lower operating costs per unit of biogas produced compared to the fixed dome and floating drum digesters. The study asserted that the tubular digester was deemed to be more sustainable when compared to the other types but with a prime concern to its low reliability (40\%). Sovacool et al. [5] compared the features of three designs. The comparison showed the lowest retention time for the tubular digester at 15 days which greatly influence 
digester size and cost. All results of other features compared in the study were favourable to tubular biogas systems. The survey of plastic tube digesters in Kenya conducted in 2009 [50] indicated that the opportunity cost of not collecting firewood, and the utilization of animal waste for energy were the main drivers to uptake the tubular digesters, in addition to energy for cooking and improved farm sanitation. The economic and technical characteristics of the tubular biogas digester eliminate most of the barriers known to slow the dissemination of biogas technology in rural areas of Kenya, and its advantages by far outweigh its disadvantages and make it the most practical design to be used in rural areas of Kenya, although there is a concern regarding end of life disposal.

\subsection{Community Based Biogas Business Model}

\subsubsection{Economic viability financial parameters}

The small community biogas plant as a business model was designed to produce up to $13.35 \mathrm{~m}^{3}$ of biogas on daily basis, the operating costs and revenues are shown as per Table 3.

Table 3: Daily operating costs and cash flow analysis

\begin{tabular}{|lc|}
\hline Daily operating costs and revenues \\
\hline Water & $0.14 €$ \\
Labour Cost/Day & $2.61 €$ \\
Daily Maintenance @ 5\% Capex & $0.20 €$ \\
Manure Cost & $0 €$ \\
Daily Opex & $2.96 €$ \\
Daily Revenue & $8.45 €$ \\
Daily Income & $5.49 €$ \\
& \\
\hline Key feasibility indicators & \\
\hline Based on 5 years operation \& 3\% discount rate \\
NPV & $2,764 €$ \\
IRR & $56 \%$ \\
IRR on discounted cash flow & $51 \%$ \\
Discounted Payback period & 20 months \\
Biogas breakeven price & $0.442 € /$ Kg \\
\hline
\end{tabular}

Biogas for cooking for 5 households based on $1.2 \mathrm{~m}^{3}$ per household/daily is $6 \mathrm{~m}^{3}$. In addition, biogas for lighting based on the assumption of 2 biogas lamps in 5 households for a period of three hours daily (estimated biogas lamp consumption of $\mathrm{h} 150 \mathrm{~L}_{\text {biogas }}(\mathrm{h})$ [51], [52], the biogas needed is $4.5 \mathrm{~m}^{3}$. Therefore, a gas surplus of $2.85 \mathrm{~m}^{3}$ will potentially be available. The additional surplus is expected as supported by the finding of a study in Nakuru district[19] which stated that only $14 \%$ of the biogas plant owners utilized biogas for lighting. But unforeseen demand may be evident as energy for cooking was estimated upon the daily firewood consumption. In fact, other fuels may be in use and may lead to a higher demand for energy for cooking demand than estimated; in addition to neighboring consumers who have the same demand. At the end, demand for domestic energy exists and biogas has other uses than cooking and lighting.

This model delivers a kilogram of biogas at a breakeven price of $0.442 € / \mathrm{kg}$ which is a $4.3 \%$ higher cost than its equivalent deliverable energy from kerosene, but $46.85 \%$ lower cost than its equivalent firewood deliverable energy. The biogas price to end user is projected at $0.55 € / \mathrm{kg}$, saving $33 \%$ on deliverable firewood energy on estimated daily savings. On the basis of five years of 
continuous operation the business model's net present value showed positive results indicating the viability of the project, see Table 3. The results also show a high internal rate of return, which give good room to accommodate for higher discount rate if a credit facility or inflation rate are considered or imply escalation of the discount rate, the project will pay back its original cost of investment in 20 months. This is comparable to biogas plant payback period of less than 22 month [30].

Table 4: Household biogas consumption and cost savings, business model

\begin{tabular}{|l|c|c|c|}
\hline & Firewood & Biogas & Kerosene \\
\hline Daily energy - kWh & 4.7 & 4.7 & 4.7 \\
\hline Daily Fuel consumption - kg & 11.4 & 1.21 & 0.79 \\
\hline Fuel cost $€ / \mathrm{kg}$ & $€ 0.09$ & $€ 0.55$ & $€ 0.65$ \\
\hline Daily Expenditure & $€ 1.01$ & $€ 0.67$ & $€ 0.52$ \\
\hline Daily saving using biogas & $€ 0.34$ & $€$ & $€(0.1)$ \\
\hline Annual saving on cooking & $€ \mathbf{1 2 4}$ & & \\
\hline $\begin{array}{l}\text { Medical expenses saved est. } \\
\text { Saving on fertiliser est. }\end{array}$ & $€ \mathbf{8 0}$ & & \\
\hline $\begin{array}{l}\text { Overall household estimated } \\
\text { annual savings }\end{array}$ & $€ \mathbf{4 5 9}$ & & \\
\hline
\end{tabular}

\subsubsection{Cost saving by household using biogas for cooking}

Replacing firewood by biogas for cooking could save each of the households around (124€) annually, equivalent to 33.6\% energy cost savings see Table 4. A study by Dohoo et al [13] on Kenyan farms with and without biogas plants indicated that money spent on firewood reduced from (384 to 112KSh per household per week) equal to annual cost savings of (125€). Comparing Dohoo et al, results with the business model's energy cost saving indicate reliability of the business model projected savings. Additional associated savings include saving on chemical fertilizers, cut in medical expenses as estimated in [53] between 60$100 €$, shown in Table 4, the business model estimate an annual cost saving for each of the households' is estimated as $249 €$. Although replacing kerosene by biogas for cooking will incur additional cost of $0.1 € /$ day, kerosene in Kenya is highly subsidized and its actual price is not shown in the market, moreover kerosene supplies are not reliable. Other non-monetized benefits of biogas are the smoke free indoors and cleanliness of biogas. The availability of the cooking fuel at the point and time of use (readiness) is one of the differential benefits between biogas and the other biomass cooking fuels. Furthermore, the value of time saved in long hours of cooking, walking long distances to buy or collect firewood, increased revenues of agricultural crops by $25 \%$, time utilized for education, the opportunity to establish small scale businesses and the improved overall well-being of the households in rural areas are advantages of biogas [30], [53].

\subsubsection{Sensitivity analysis}

The impacts of substrate partial collection on NPV is shown in Figure 5 Increasing the quantity of the $337.5 \mathrm{~kg}$ of cattle manure results in an increased biogas yield, which has a positive impact on the viability of the project. The increase can be by means of increasing the number of cattle or collection from other resources than the 5 households. However, the capacity of the digesters will not accommodate the additional quantities. Decreasing the quantity to less than $80.4 \%$ of the available substrate result in lower biogas yield and a non-profitable business, hence the biogas plant should operate on a minimum of $85 \%$ (286kg) of the model's design substrate input. 
Impact of operating cost elements on net present value

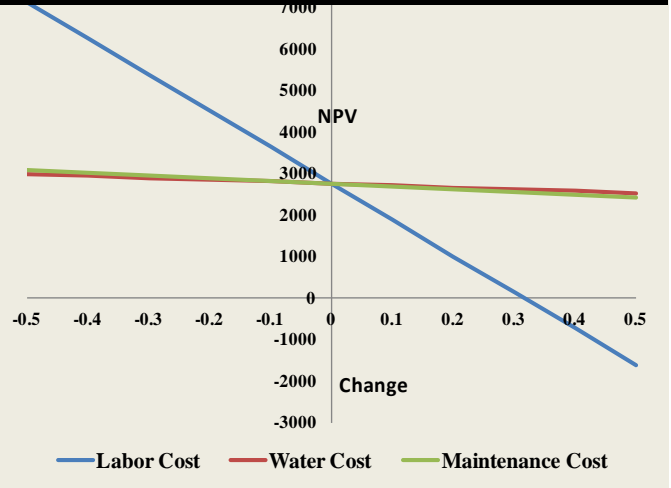

Figure 6: Sensitivity analysis of the business model

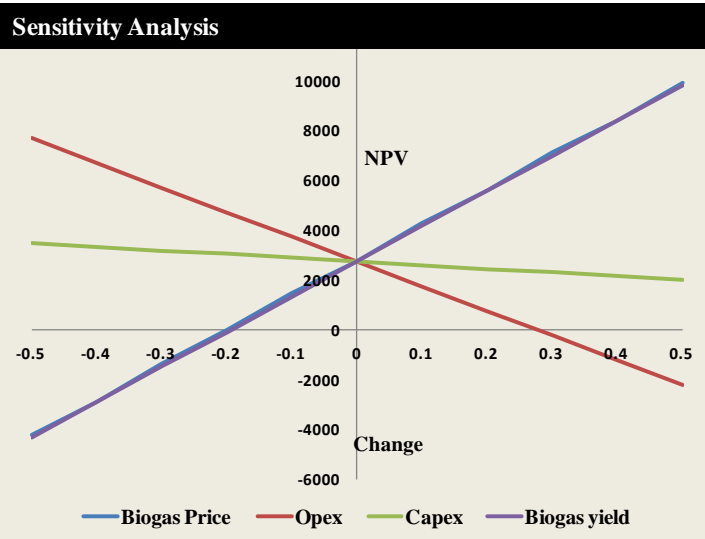

Figure 5: Sensitivity analysis considering operating expenses

The biogas price has high significance on the viability of the business model. Any increase in price results in high net present value while reducing the price by more than $20 \%$ or less than $0.44 € / \mathrm{kg}_{\text {biogas }}$ result in negative NPV, this corresponds to the model breakeven price. The impact on NPV of operating costs (Opex) has high significance on the business model viability as shown in Figure 5. The graph indicates negative NPV when operating costs increase by more than $20 \%$. Of the three operating elements, labor cost has the highest impact on NPV as shown in Figure 6.

However, the impact of capital investment cost (Capex) on NPV (Figure 5) does not have signifcant effects. Increasing the capital cost to 2,212.5€ (50\%) still results in positive NPV indicating 1.3 more digesters can be accommodated within the same business model boundaries supported by the non-significant impact of the maintenance cost (based on capital cost) on the project viability, shown in Figure 6 . However, practically operating three or more digesters will escalate the labor cost which has significant effect on the project's feasibility unless an additional quantity of biogas is produced. Such a change requires optimisation of all the parameters to achieve a viable return on investment.

The sensitivity analysis indicated the high significance of biogas revenues represented by either biogas yield or biogas price on the profitability of the business model. Furthermore, the high impact of the operating costs, with the labor cost play a major role. Accordingly, simple assessment of the risks associated with running this business model can be summarized as: the risk of increasing labor cost remain high, since minimum wages are decided by the government, and the load of operations may require more labor to be involved. This can be catered for at the expense of consumers' energy cost savings, although the projected price provide room for the biogas price to increase up to $33 \%$ offsetting the cost savings initially projected.

Another risk is a reduced biogas price which is not evident, since no driver is anticipated. Attainable savings, shortage of firewood, and the added benefits of using biogas outweigh any savings from further reduction of biogas price. Furthermore, biogas production may be affected by the production inputs such as a shortage of water. Water buffer stocks will eliminate this risk, and substrate availability may be affected by reduction of the number of cattle which can be outsourced and may incur an additional cost. Malfunctioning of the digesters will affect the quantity of gas produced and require proper operation. Biogas international Ltd. provides training on operation and maintenance upon installation of the flexi-bag digesters. Some biogas equipment and appliances are available in the Kenyan market for better plant operations and utilization of biogas [54]. Adding a biogas storage facility to the plant will increase reliability of operations and supplies. In the end, the business owners' commitment to operational excellence is important for the success of this biogas business model.

\section{CONCLUSION}

This study aimed to investigate the potential and viability of biogas to provide clean and affordable domestic energy in rural Kenya. Through a review of biogas resources and biogas digesters installed in Kenya, along with an assessment of the suitable digesters, a feasibility analysis of a suggested business model was developed. The results indicated high technical potential for biogas in central and western Kenya, where, in general, land and cattle manure resources are available, although water availability is a challenge. The inflatable plug flow digester was found to be the most suitable in meeting the current economic and social conditions in rural Kenya, owing to low cost and ease of operation. Indeed, it is suggested that this technology should be strongly encouraged to contribute towards meeting the targets of the Kenyan Biogas Development Programme. Mitigating biogas technology barriers, the study suggested community biogas entrepreneurship projects as a recommended solution. Ownership and even co-design has been shown to improve the success of rural energy interventions [55]. The economic viability of the business 
model was investigated and the results from this showed that a profitable business could be maintained through supplying biogas for cooking and lighting. Biogas priced at $0.55 € / \mathrm{kg}$ offered household energy cost savings of around $35 \%$, or $249 €$ annually. However, assessing the sensitivity of the economic parameters on the viability of the business model showed that the model was susceptible to operating cost and biogas revenue changes. These could be a threat operationally as well as to the viability of the biogas development programme. It is recommended that these critical risks are addressed in the future deployment of digesters and implementation policies. Therefore, it has been demonstrated that Kenya's rural areas have the potential to utilize biogas to meet domestic needs, reduce expenditure and to contribute to social development.

\section{ACKNOWLEDGMENT}

The authors of this paper would like to express their gratitude and sincere appreciation to Dominic Wanjihia CEO/Lead Engineer at Biogas International Ltd. for the useful information and comments. This research did not receive any specific grant from funding agencies in the public, commercial or not-for-profit sectors.

\section{REFERENCES}

[1] Dalberg, “GLPGP - Kenya Market Assessment,”2013. [Online]. Available: https://cleancookstoves.org/binarydata/RESOURCE/file/000/000/234-1.pdf [Accessed 4-Apr-2017].

[2] Rural 21, "Woodfuels in Kenya and Rwanda : powering and driving the economy of the rural areas," 2/2011, p. 26,27, 2011.

[3] A. Hamlin, “Assesment of Social and Economic Impacts of Biogas Digesters in Rural Kenya,” SIT Digit. Collect., pp. 6-7, 2012.

[4] Kenya Institute for Public Policy Research and Analysis (KIPPRA), “A Comprehensive Study and Analysis on Energy Consumption Patterns in Kenya: A Synopsis of the Draft Final Report,” no. July 2010, p. 20, 2010.

[5] B. K. Sovacool, M. Kryman, and T. Smith, "Scaling and commercializing mobile biogas systems in Kenya: A qualitative pilot study," Renew. Energy, vol. 76, no. April, pp. 115-125, 2015.

[6] P. T. R. Thy and L. J, "Effect of retention time on gas production and fertilizer value of biodigester effluent,” Livest. Res. Rural Dev., vol. 15, no. 7, 2003.

[7] K. Ileleji, C. Martin, and D. Jones, “Basics of Energy Production through Anaerobic Digestion of Livestock Manure,” Purdue Ext., 2008.

[8] T. Bond and M. R. Templeton, "History and future of domestic biogas plants in the developing world," Energy Sustain. Dev., vol. 15, no. 4, pp. 347-354, 2011.

[9] D.A.F.F, “Manure production data,” 2012. [Online]. Available: http://www.daff.qld.gov.au/environment/intensive-livestock/cattlefeedlots/managing-environmental-impacts/manure-production-data [Accessed 4-Apr-2017].

[10] B. Brown, “How much fertilizer do your animals produce ?” [Online]. Available: http://learningstore.uwex.edu/Assets/pdfs/A3601.pdf [Accessed 4-Apr-2017].

[11] S. C. Bhattacharya, J. M. Thomas, and S. P. Abdil, "Greenhouse gas Emissions and the Mitigation Potential of Using Animal Wastes in Asia,” Energy, vol. 22, no. 11, pp. 1079-1085, 1997.

[12] Kenya National Bureau of Statistics, Economic Survey 2015. Nairobi, Kenya, 2015

[13] C. Dohoo, J. VanLeeuwen, J. Read Guernsey, K. Critchley, and M. Gibson, "Impact of biogas digesters on wood utilisation and selfreported back pain for women living on rural Kenyan smallholder dairy farms.,” Glob. Public Health, vol. 8, no. 2, pp. 221-235, 2013.

[14] Biomass Energy Centre, “Typical calorific values of fuels,” 2014. [Online]. Available: http://www.biomassenergycentre.org.uk/portal/page?_pageid=75,20041\&_dad=portal\&_schema=PORTAL. [Accessed: 14-Jul-2015].

[15] Center for Energy Studies, “Efficiency Measurement of Biogas, Kerosene and LPG Stoves,” 2001.

[16] P. J. Jørgensen, Biogas - green energy. PlanEnergi and Faculty of Agricultural Science, Arhus University, Arhus, 2009.

[17] “LPG Density.” [Online]. Available: http://www.total.co.in/lpg-b2c/know-more-about-totalgaz-b2c/technical_specification.html. [Accessed: 15-Jul-2015].

[18] Http://physics.info/, “Kerosene density.” [Online]. Available: http://physics.info/density/. [Accessed: 15-Jul-2015].

[19] J. W. Mwirigi, P. M. Makenzi, and W. O. Ochola, "Socio-economic constraints to adoption and sustainability of biogas technology by farmers in Nakuru Districts, Kenya,” Energy Sustain. Dev., vol. 13, no. 2, p. 110, 2009.

[20] OANDA, “Money Exchange Rate.” [Online]. Available: http://www.oanda.com/currency/converter/. [Accessed: 27-Jul-2015].

[21] Biogas International ltd, “Biogas International Ltd ,”[Online]. Available: http://biogas.co.ke/en/ [Accessed: 15-Jul-2015].

[22] Biogas International ltd, “Flexi biogas systems.”[Online] Available: http://biogas.co.ke/en/Biogas\%20International\%20Ltd_Brochure_2015.pdf [Accessed: 4-Apr-2017].

[23] E. Ng'wandu, L. Shila and F. ter Heegda. Programme Implementation Document, “Tanzania Domestic Biogas Programme,” [Online]. Available: http://area-net.org/wp-content/uploads/2016/01/Tanzania_Biogas_Programme.pdf [Accessed 4-Apr-2017]..

[24] Wikipedia, "Water supply and sanitation in Kenya.” [Online]. Available: https://en.wikipedia.org/wiki/Water_supply_and_sanitation_in_Kenya. [Accessed: 13-Jul-2015].

[25] World Bank Water Sanitation Program. “An AMCOW Country Satus Overview Water Supply and Sanitation in Kenya,” World Bank, Nairobi, Kenya. 2015.

[26] “Minimum Wages in Kenya with effect from 01-05-2015.” [Online]. Available: http://www.mywage.org/kenya/home/salary/minimumwage. [Accessed: 17-Jul-2015].

[27] CO2balance, “Market Segmentation Study.” [Online]. Available: http://cleancookstoves.org/resources/230.html [Accessed 4/Apr-2017]. 
[28] F. Mugo and T. Gathui, "Biomass energy use in Kenya: A background paper prepared for the International Institute for Environment and Development.” Practical Action, Rugby, UK, 2010.

[29] J. U. Smith, "The Potential of Small-Scale Biogas Digesters to Alleviate Poverty and Improve Long Term Sustainability of Ecosystem Services in Sub-Saharan Africa,” Department for International Development, UK, 2012.

[30] L. Warnars and H. Oppenoorth, “A study on bioslurry results and uses,” no. March, K. Atkinson, Ed. 2014, pp. $20,35,42$.

[31] J. K. Kiplagat, R. Z. Wang, and T. X. Li, “Renewable energy in Kenya: Resource potential and status of exploitation,” Renew. Sustain. Energy Rev., vol. 15, no. 6, pp. 2960-2973, 2965, 2011.

[32] Smallholder Dairy Project, "The Uncertainty of Cattle Numbers in Kenya", SDP Policy Brief 10, Nairobi, 2006.

[33] Ashington Ngigi, “Kenya National Domestic Biogas Programme.” Tech. Rep. p. 33, 2009.

[34] S. J. Staal, M. Owango, H. Muriuki, M. Kenyanjui, B. Lukuyu, L. Njoroge, D. Njubi, I. Baltenweck, F. Musembi, O. Bwana, K. Muriuki, G. Gichungu, A. Omore, and W. Thorpe, “SDP Research Report,” Nairobi Kenya, 2001.

[35] A. Kirigia, J. T. Njoka, P. I. D. Kinyua, and T. P. Young, "Characterizations of livestock manure market and the income contribution of manure trade in Mukogodo ,” vol. 8, no. 46, pp. 5864-5871, 2013.

[36] C. Nzila, J. Dewulf, H. Spanjers, H. Kiriamiti, and H. van Langenhove, “Biowaste energy potential in Kenya,” Renew. Energy, vol. 35, no. 12, pp. 2698-2704, 2010.

[37] Water.org, “Kenya,” 2012. [Online]. Available: http://water.org/country/kenya/. [Accessed: 02-Aug-2015].

[38] Reliefweb, “Kenya: Drought - 2014-2015,” 2015. [Online]. Available: http://reliefweb.int/disaster/dr-2014-000131-ken. [Accessed: 02Aug-2015].

[39] M. Waithaka, J. Nyangaga, S. Staal, A. Wokabi, D. Njubi, K. Muriuki, L. Njoroge, and P. Wanjohi, “Characterization of dairy systems in the western Kenya region,” Nairobi, 2002.

[40] ILRI, "Smallholder dairy production and marketing - Opportunities and constraints," Proc. a South-South Work. held Natl. Dairy Dev. Board Anand, India, 13-16 March 2001, no. March, p. 161, 2001.

[41] B. X. An, J. Rodriguez, S. Sarwatt, T. Preston, and F. Dolherg, "Installation and performance of low-cost polyethylene tube biodigesters on small-scale farms,” World Animal Review, vol. 88, no. 1. pp. 38-47, 1997.

[42] K. Hagegård, "Small-Scale Biogas by Lake Victoria Analyzing and implementing the biogas technology for cooking in rural African households,” Report 100663CL, Chalmers University of Technology, Sweden, 2008.

[43] C. Nzila, J. Dewulf, H. Spanjers, D. Tuigong, H. Kiriamiti, and H. van Langenhove, "Multi criteria sustainability assessment of biogas production in Kenya,” Appl. Energy, vol. 93, pp. 496-506, 2012.

[44] Kenya National Federation of Agricultural Producers. "KENBIM Domestic Biogas Training Manual". KENDBIP, Nairobi, Kenya, 2009.

[45] L. C. Cooperative, “Kenya National Domestic Biogas Programme 2011 Annual Report,” International Institute for Environment and Development UK, 2011.

[46] S. Gitonga, "Biogas Promotion in Kenya A review of experiences,” [Online] Available: https://www.doc-developpementdurable.org/file/Energie/biogaz/Biogas\%20Promotion\%20in\%20Kenya.pdf [Accessed 4-Apr-2017].

[47] African Breeders Services, “Kentainers,” 2015. [Online]. Available:

http://www.abstcm.com/index.php?option=com_content\&view=article\&id=188\&Itemid=223. [Accessed: 18-Jul-2015].

[48] K. Rajendran, S. Aslanzadeh, and M. J. Taherzadeh, “Household biogas digesters-A review,” Energies, vol. 5, no. 8, pp. 2911-2942, 2012.

[49] IFAD, “Flexi Biogas systems: inexpensive, renewable energy for developing countries,” 2012. [Online]. Available: www.ifad.org/pub/thematic/biogas.pdf. [Accessed 4-Apr-2017].

[50] F. X. Ochieng, "Survey of Plastic Tube Digesters in Kenya,” Deutsche Gesellshaft für Technische Zusammentarbeit (GTZ) GmbH, 2010.

[51] V. Tumwesige, D. Fulford, and G. C. Davidson, “Biogas appliances in Sub-Sahara Africa,” Biomass and Bioenergy, vol. 70, p. 46, 2014.

[52] K. C. Surendra, D. Takara, A. G. Hashimoto, and S. K. Khanal, "Biogas as a sustainable energy source for developing countries: Opportunities and challenges,” Renew. Sustain. Energy Rev., vol. 31, pp. 846-859, 2014.

[53] J. Smith, "The Potential of Small-Scale Biogas Digesters to Alleviate Poverty and Improve Long Term Sustainability of Ecosystem Services in Sub-Saharan Africa,” pp. 1-57, 2012.

[54] Takamoto, "Biogas Appliances.” [Online]. Available: http://takamotobiogas.com/products/biogas-appliances/. [Accessed: 12-Aug2015].

[55] Blanchard, R. E., Brown, E., Clements, A., Cloke, J., \& Mohr, A. (2017). Theory and praxis: The complexities of co-design in community energy projects in Kenya. Poster session presented at Energy for Society: 1st International Conference on Energy Research and Social Science. Sitges, Spain. 